\title{
ROADMAP OF HEALTH DEVELOPMENT IN WEST MANGGARAI DISTRICT, EAST NUSA TENGGARA 2016-2021
}

\author{
Frans Salesman
}

\author{
Faculty of Public Health, Cendana University
}

\begin{abstract}
Background: West Manggarai is one of districts in East Nusa Tenggara with population health indicators lagged behind: (1) High infant mortality rate; (2) High maternal mortality ratio; (3) High prevalence of severe or moderate child malnutrition; (4) High incidence of low birth weight infants; (5) High incidence of HIV infection, tuberculosis, diarrhea, and fever; (6) Low participation of couples of childbearing age in family planning program; (7) Low life expectancy at birth; (8) High poverty; (9) Low competitiveness of the population to enter the global life. The purpose of this study was to provide a summary of the health development roadmap in West Manggarai, East Nusa Tenggara, 2016-2021.

Subject and Method: This was a qualitative-quantitative descriptive study conducted in West Manggarai, East Nusa Tenggara. The data were collected by in-depth interview, focus group discussion (FGD), and document review. Data sources included Central Bureau Statistic (Biro Pusat Statistik, BPS), health profile of District Health Office. The FGD participants comprised of 35 participants.

Results: With reference to National Health System, West Manggarai District Health Development policies had been formulated to include some key objectives as follows: (1) Community development for healthy behavior; (2) Quality improvement in primary health services and referral services; (3) Quality improvement in maternal, child, adolescent, and elderly health services; (4) Community nutrition improvement; (5) Improvement in disease control and environmental health; (6) Increase in number of medical doctors and paramedics; (7) Improvement in availability and distribution of pharmaceuticals, medical equipments, food and drink; (8) Expansion of BPJS health financing coverage; (9) Upgraded status of Labuan Bajo Hospital from Type-C to BLUD; (10) Formulation of local regulation on local health system and regency regulation on local health sub-system; (11) Decline in total fertility rate.

Conclusion: Based on problem identification, analysis of local resources potential, and conforming to the National Health System, West Manggarai Roadmap of Health Development 2016-2021 has been formulated to address and overcome important population health problems in the district.
\end{abstract}

Keywords: Roadmap of health development, population health problems

Correspondence: Frans Salesman. Faculty of Public Health, Cendana University. Email: franssalesman@gmail.com. Mobile: +6281337909998. 